\title{
GURU KELAS SEBAGAI FASILITATOR DI SEKOLAH DASAR
}

\author{
Hasna1, Kabiba ${ }^{2}$, dan Nurzaima ${ }^{3}$ \\ Program Studi Administrasi Pendidikan, Universitas Muhammadiyah \\ Kendari ${ }^{123}$ \\ Email: hasnazaidin78@gmail.com
}

\begin{abstract}
ABSTRAK
Tujuan penelitian adalah untuk mengetahui peran guru kelas sebagai fasilitator di Sekalah Dasar Negeri 4 Batukara Kecamatan Batukara Kabupaten Muna. Teknik pengumpulan data yang digunakan dalam penelitian ini berupa observasi, wawancara, dan dokumentasi. Teknik analisis data yang digunakan dalam penelitian ini adalah seleksi data, klasifikasi data dan menarik kesimpulan. Berdasarkan hasil penelitian dan pembahasan, menunjukan bahwa peran peran guru kelas sebagai fasilitator di Sekolah Dasar Negeri 4 Batukara Kecamatan Batukara Kabupaten Muna sudah menyediakan perangkat-perangkat pembelajaran. Guru menyadari bahwa untuk mengejar di sekolah Dasar guru kelas harus menjadi inisiator agar prosess belajar dapat berjalan maksimal dan tidak membebankan perangkat pembelajaran kepada siswa dalam pengadaannya maupun penyediaan fasilitas pembelajaran yaitu sarana dan prasarana yang dapat digunakan siswa-siswi dalam belajar. Guru kelas sudah bertindak sebagai mitra yaitu guru kelas selalu memberikan andil bagi siswa-siswi terlibat dalam proses belajar dan guru kelas bertindak sebagai mitra sehingga guru kelas dapat mengetahui karakter-karakter peserta didiknya. Guru kelas yang ada di SD Negeri 4 batukara sudah menjalankan tugas dan fungsinya.
\end{abstract}

Kata Kunci: guru Kelas; fasilitator

\section{ABSTRACT}

Research objectives to determine the role of classroom teachers as facilitators in Sekalah Dasar Negeri 4 Batukara, Batukara District, Muna Regency. Data collection techniques used in this study were observation, interviews, and documentation. Data analysis techniques used in this study were data selection, data classification and drawing conclusions. Based on the results of research and discussion, it shows thatrolethe role of the classroom teacher as a facilitator in the Batukara 4 State Elementary School, Batukara District, Muna Regency, has provided learning tools, this is what they realize that to catch up in elementary schools the classroom teacher must become an initiator so that the learning process can run optimally and not burden learning tools on students in organize it, provide learning facilities, in this case the facilities and infrastructure that can be used by students in learning, the class teacher has acted as a partner, for example the class teacher always contributes to the students involved in the learning process and the class teacher acts as a partner so the class teacher know the characters of students, The class teachers in SD Negeri 4 Batukara have already carried out their duties and functions, especially in grade V and Grade VI, who have not acted arbitrarily towards their students.

Keywords: classroom teacher; fasilitator 


\section{PENDAHULUAN}

Guru merupakan salah satu faktor penentu keberhasilan setiap upaya pendidikan. Demikian pun dalam upaya membelajarkan siswa, guru dituntut memiliki multi peran sehingga mampu menciptakan kondisi belajar mengajar yang efektif (Usman, 2007: 5). Sebagaimana yang dikemukakan oleh Sanjaya (2006: 26) peranan guru dalam proses pembelajaran adalah guru sebagai sumber belajar, fasilitator, pengelola, demonstrator, pembimbing, motivator, dan evaluator. Sebagai fasilitator guru berperan memberikan pelayanan untuk memudahkan siswa dalam proses pembelajaran. Dalam implementasi pembelajaran berbasis aktivitas siswa, guru tidak lagi berperan sebagai satu-satunya sumber belajar, akan tetapi yang lebih penting adalah bagaimana memfasilitasi agar siswa belajar. Seiring dengan diterapkannya kurikulum 2013 yang berbasis kompetensi sekaligus berbasis karakter, kunci sukses dari keberhasilan kurikulum ini ditentukan oleh kreatifivitas guru, karena disini guru merupakan faktor penting yang besar pengaruhnya, bahkan sangat menentukan berhasil atau tidaknya peserta didik.

Guru sebagai fasilitator yakni berperan sebagai fasilitator, guru dalam hal ini akan memberikan fasilitas atau kemudahan dalam proses pembelajaran, misalnya saja dengan menciptakan suasana kegiatan belajar yang sedemikian rupa, serasi dengan perkembangan anak sehingga interaksi pembelajaran akan berlangsung secara efektif, dan mengolah informasi menuju tujuan belajar mengajar yang telah direncanakan. Guru dalam melaksanakan tugas profesinya selalu dihadapkan pada berbagai pilihan, karena kenyataan di lapangan kadang tidak sesuai dengan harapan, seperti cara bertindak, bahan belajar yang paling sesuai, metode penyajian yang paling efektif, alat bantu yang paling cocok, langkah-langkah yang paling efisien, sumber belajar yang paling lengkap, sistem evaluasi yang sesuai. Meskipun guru sebagai pelaksana tugas otonom, guru juga diberikan keleluasaan untuk mengelola pembelajaran, dan guru harus dapat menentukan pilihannya dengan mempertimbangkan semua aspek yang relevan atau menunjang tujuan yang hendak dicapai. Dalam hal ini guru bertindak sebagai pengambil keputusan. Sebagai fasilitator guru hendaknya mampu mengusahakan sumber belajar yang berguna serta dapat menunjang pencapaian tujuan dan proses belajar mengajar, baik yang berupa narasumber, buku, teks, majalah, ataupun surat kabar.

Hal-hal yang perlu dilakukan oleh seorang fasilitator agar proses belajar berlangsung secara efektif, seperti dikemukakan oleh Parker (2007: 24) yaitu : memahami audience, menjelaskan peranan fasilitator, membuat kesepakatan tentang materi yang akan dibahas dan proses yang akan digunakan, mengelola proses serta membangun kepercayaan dan kerjasama selama proses berlangsung, memberikan pertanyaan kepada peserta dalam bentuk pertanyaan terbuka, menjaga agar setiap orang tetap terlibat, dan menghindarkan diri sebagai pusat perhatian, melakukan intervensi pada saat diperlukan, membuat ringkasan dan menarik kesimpulan. Tugas utama fasilitator adalah membantu semua orang untuk dapat mengeluarkan pendapat, pikiran dan melakukan yang terbaik dalam sebuah pertemuan atau diskusi (Denny Boy Mochran, dkk, 2014: 1). Esi (2016) dalam penelitiannya tentang peranan guru sebagai fasilitator dan motivator dalam meningkatkan hasil belajar di kelas xi SMK. Hasil penelitian menunjukkan bahwa peranan guru sebagai fasilitator dan motivator dalam meningkatkan hasil belajar siklus akuntansi 2 di kelas XI AK 3 masuk dalam kategori sangat baik dengan persentase $81,2 \%$.

SD Negeri 4 Batukara Kabupaten Muna merupakan salah satu sekolah dasar di Kecamatan Batukara. Siswa-Siswi SD batukara memiliki sejumlah prestasi 
dibanding sekolah-sekolah lain yang ada di Kecamatan Batukara. Keberhasilan siswa-siswi SD Batukara tentunya tidak terlepas dari peran guru yang ada di SD Negeri Batukara salah satunya adalah guru kelas. Kemahiran dalam memotivasi siswa-siswinya adalah salah satu kunci keberhasilan SD Negeri Batukara dibanding sekolah-sekolah dasar lainnya yang ada di Batukara. Dengan demikian penelitian ini menfokuskan untuk mengetahui peran guru kelas sebagai fasilitator di Sekolah Dasar Negeri 4 Batukara Kecamatan Batukara Kabupaten Muna.

\section{METODE PENELITIAN}

Jenis penelitian yang digunakan adalah kualitatif, yakni data yang berbentuk kata, skema, dan gambar. Artinya data yang dikumpulkan bukan berupa angkaangka, melainkan data tersebut berasal dari hasil wawancara, catatan lapangan, dokumen pribadi, dan dokumen resmi lainnya. Sehingga yang menjadi tujuan dari penelitian kualitatif ini adalah ingin menggambarkan realita empirik dibalik fenomena secara terperinci, mendalam, dan tuntas tentang sumber data. Subjek penelitian adalah sesuatu yang diteliti baik orang, benda atau lembaga. Subjek penelitian pada dasarnya adalah sesuatu yang akan dikenai kesimpulan hasil penelitian

Teknik pengumpulan data yang digunakan dalam penelitian ini adalah (1) observasi yaitu dalam penelitian ini penulis melakukan observasi mengenai peran guru kelas sebagai fasilitator di sekolah khususnya Sekolah Dasar Negeri 4 Batukara. Observasi ini diusahakan dalam situasi yang alami, agar dapat memperoleh data yang sebenarnya. (2) Wawancara dilakukan di sekolah (ruang guru) dengan memberikan sebuah pertanyaan kepada informan dengan berdasar pada pedoman wawancara yang telah dibuat. Peneliti mengadakan wawancara dengan sejumlah guru-guru yang telah di tunjuk untuk memperoleh data yang lebih mendalam dan akurat. (3) Dokumentasi, penggunaan teknik ini dimaksudkan untuk mengkaji dokumen tentang data-data yang relevan dengan variabel penelitian. Dokumentasi merupakan cara pengumpulan data berupa data yang sudah jadi atau laporan. Analisis data yang digunakan dalam penelitian ini adalah (1) reduksi data (data reduction). Reduksi data yaitu sebagai proses pemilihan, pemusatan, dan perhatian pada penyederhanaan dan transformasi data dasar atau data mentah dari pihak guru yang memberikan informasi terhadap peranan guru dalam pembelajaran. (2) Penyajian data (data display). Penyajian data dilakukan untuk memperjelas hubungan atau gambaran yang tepat tentang keseluruhan data yang diperoleh guna mengungkap tentang peranan guru dalam pembelajaran terhadap hasil belajar siswa di SD Negeri 4 Batukara Kecamatan Batukara Kabupaten Muna. (3) Verifikasi atau Penarikan kesimpulan (veification), didukung hasil observasi dan wawancara terhadap guru, sehingga diperoleh kesimpulan secara akurat dan dapat dipercaya mengenai peranan guru dalam pembelajaran terhadap hasil belajar siswa siswa di SD Negeri 4 Batukara. Uji keabsahan data yang digunakan adalah triangulasi sumber, triangulasi teknik, dan triangulasi waktu (Sugiyono, 2007:273).

\section{HASIL PENELITIAN DAN PEMBAHASAN \\ HASIL PENELITIAN}

Hasil penelitian terkait peran guru kelas Sebagai fasilitator di Sekalah Dasar

Negeri 4 Batukara Kecamatan Batukara Kabupaten Muna yaitu:

\section{Guru Kelas Menyediakan Seluruh Perangkat Pembelajaran.}

Berdasarkan hasil penelitian dan data yang ditemukan di lokasi penelitian pada saat melakukan penelitian bahwa peran guru kelas sebagai fasilitator di SD Negeri 4 Batukara dapat diartikan sebagai individu yang mempunyai keterampilan 
untuk memudahkan, membimbing dan memberi semangat kepada siswa. Fasilitator bertindak sebagai pemandu bagi pelajar dalam menyelesaikan masalah-masalah yang dihadapi. Selain itu, fasilitator juga berfungsi sebagai seseorang yang memicu kreativitas dari para siswa. Guru merupakan faktor yang sangat penting dalam menunjang kesuksesan para siswa dalam belajar. Dalam rangka meningkatkan efektivitas pembelajaran siswa, guru mempunyai peran penting dalam proses belajar mengajar. Guru sebagai fasilitator artinya para siswa diizinkan untuk menentukan kebutuhan dan tujuan pembelajaran dengan memanfaatkan dari berbagai sumber.

SD Negeri 4 Batukara memiliki perangkat pembelajaran dalam menunjang belajar siswa-siswinya. Perangkat pembelajaran yaitu media yang dipakai sebagai petunjuk atau pedoman dalam proses belajar mengajar. Tujuan dari adanya perangkat pembelajaran yaitu untuk membantu guru dalam menjelaskan suatu permasalahan. Perangkat pembelajaran ini digunakan para guru dalam proses belajar mengajar baik di laboratorium maupun di kelas. Dalam perencanaan pembelajaran tersebut semuanya sudah disiapkan mulai dari sumber belajar, perangkat penilaian dan skenario pembelajaran. Guru kelas menyediakan seluruh perangkat pembelajaran di SD Negeri 4 Batukara, hal ini mereka sadari bahwa untuk mengajar di sekolah dasar, guru kelas harus menjadi inisiator agar proses belajar dapat berjalan maksimal dan tidak mungkin perangkat pembelajaran dibebankan kepada siswa dalam pengadaannya. Disisi lain para guru kelas juga menyadari bahwa tersedianya seluruh perangkat pembelajaran bisa meningkatkan kualitas belajar siswa-siswi SD Negeri 4 Batukara.

\section{Guru Kelas Menyediakan Fasilitas Pembelajaran}

Berdasarkan hasil penelitian dan data yang ditemukan di lokasi penelitian pada saat pengumpulan data bahwa peran guru kelas sebagai fasilitator dilihat dari indikator guru kelas menyediakan fasilitas pembelajaran di SD Negeri 4 Batukara. Fasilitas terbagi menjadi dua yaitu sarana dan prasarana. Prasarana meliputi gedung sekolah, ruang belajar, lapangan olahraga, ruang ibadah, ruang kesenian dan peralatan olahraga. Sedangkan sarana meliputi buku pelajaran, buku bacaan, alat dan fasilitas laboratorium. Fasilitas belajar ini adalah segala sesuatu yang dapat menunjang proses belajar mengajar dan sangat berkaitan erat dengan kondisi ekonomi orang tua siswa. Bagi orang tua yang mempunyai kemampuan finansial yang baik maka mereka dapat memenuhi kebutuhan fasilitas belajar anaknya begitu juga sebaliknya.

Hal serupa juga terjadi pada pemenuhan kelengkapan fasilitas di sekolah, jika sekolah mampu secara finansial maka kelengkapan fasilitas penunjang dapat terpenuhi dengan baik. Kelengkapan fasilitias belajar ini juga berkaitan dengan mutu atau kualitas dari anak didik, semakin lengkap maka semakin mudah para siswa-siswi dalam memahami pembelajaran. Dengan demikian, kelengkapan fasilitas belajar yang memadai dapat meningkatkan semangat belajar peserta didik.

Ketersediaan fasilitas belajar juga menjadi ukuran penilaian terhadap sekolah. Tingkat efektivitas proses belajar mengajar juga dilihat dari kelengkapan fasilitas belajar yang ada. Dalam hal ini fasilitas belajar yang paling penting yakni laboratorium, perpustakaan, komputer dan kondisi fisik lainnya yang secara langsung mempengaruhi kenyamanan belajar. Guru kelas menyediakan fasilitas pembelajaran di SD Negeri 4 Batukara, yang secara umum sudah menyedikan fasilitas pembelajaran yaitu sarana dan prasarana yang dapat digunakan siswa-siswi 
dalam belajar. Tetapi fasilitas pembelajaran lain seperti komputer belum kita dikhususkan untuk siswa karena masih belum ada dalam mata pelajaran, hal ini dikarenkan listrik belum memadai dan siswa-siswi belum terbiasa dengan penggunaan komputer. Belum menjadi kewajiban juga di SD Negeri 4 Batukara untuk penggunaan komputer.

\section{Guru Kelas Sebagai Mitra}

Berdasarkan hasil penelitian dan data yang ditemukan penulis dilokasi penelitian pada saat melakukan penelitian bahwa peran guru kelas sebagai fasilitator di SD Negeri 4 Batukara dalam hal sebgai mitra yaitu guru kelas telah mengubah pola interaksi antara guru dengan siswa, yang awalnya bersifat top-down menjadi hubungan kemitraan. Pada pola hubungan top-down, guru seringkali diposisikan sebagai atasan dimana sarat akan komando dan bersifat otoriter dan siswa diposisikan sebagai bawahan dimana mereka harus selalu patuh dengan segala yang dikehendaki oleh guru.

Berbeda dengan pola kemitraan antara guru dan siswa, guru bertindak sebagai pendamping belajar peserta didik dengan mengembangkan suasana belajar yang menyenangkan. Oleh karena itu, agar guru dapat memainkan perannya dengan baik sebagai fasilitator maka terdapat beberapa prinsip-prinsip yang harus terpenuhi, diantaranya yaitu: siswa dapat mengambil andil penuh dalam setiap aktivitas pembelajaran, pelajaran yang praktis dan dapat diaplikasikan, siswa mempuyai ruang yang cukup untuk mengembangkan keterampilannya, pembelajaran disesuaikan dengan pengalaman dan daya pikir siswa serta terbina hubungan yang baik antara guru dan siswa maupun siswa dengan siswa. Disamping itu, guru juga harus memperhatikan karakteristik-karakteristik siswanya dalam menentukan hasil belajar. Guru harus memahami bahwa setiap siswa memiliki potensi dan pengalaman yang berbeda-beda. Guru juga harus mampu mengetahui bahwa siswa lebih senang dengan hal-hal yang bersifat praktis dan siswa juga lebih menerima saran ketimbang ceramah. Untuk mengoptimalkan peran guru sebagai mitra fasilitator dikelas di SD Negeri 4 Batukara maka guru juga harus memahami hal-hal yang berkaitan dengan penggunaan media dan sumber belajar. Guru harus mencari dan menemukan media dan sumber belajar yang cocok dalam setiap kegiatan pembelajaran. Terkait dengan sikap dan perilaku guru maka terdapat halhal yang perlu diingat agar menjadi fasilitator yaitu: guru harus mampu mendengarkan dan tidak mendominasi, mampu bersabar, menghargai dan rendah hati, mau belajar, bersikap sederajat, bersikap akrab dan melebur, tidak berusaha menceramahi, berwibawa, tidak memihak dan mengkritik maupun bersikap terbuka dan positif.

Berdasarkan fakta dan data dilapangan pada saat melakukan penelitian dan dari beberapa hasil wawancara dengan informan guru kelas Di SD Negeri 4 Batukara sudah bertindak sebagai mitra misalnya guru kelas selalu memberikan andil bagi siswa-siswi SD Negeri 4 Batukara untuk terlibat dalam proses belajar, tidak bertindak sebagai eksekutor dalam proses belajar di sekolah. Disisi lain guru kelas bertindak sebagai mitra, maka guru kelas dapat mengetahui karakterkarakter siswa-siswi yang ada di SD Negeri 4 Batukara terkhsus siswa-siswi kelas V dan kelas VI.

\section{Guru Kelas Melaksanakan Tugas dan Fungsinya}

Berdasarkan hasil penelitian dan data yang ditemukan penulis dilokasi penelitian pada saat melakukan penelitian bahwa peran guru kelas sebagai fasilitator di SD Negeri 4 Batukara yaitu guru kelas melaksanakan tugas dan fungsinya. Guru mempunyai tugas dan fungsi yang sangat beragam. Tugas-tugas tersebut meliputi bidang profesi, bidang kemanusiaan dan bidang kemasyarakatan. 
Dalam bidang profesi, guru harus mendidik, mengajar dan melatih. Mendidik artinya mengembangkan nilai-nilai kehidupan. Mengajar artinya mengembangkan ilmu pengetahuan dan teknologi. Dan melatih artinya menggali dan menemukan potensi siswa. Dalam hal kemanusiaan, guru harus memposisikan dirinya sebagai orang tua dimana ia harus pandai menarik simpati para siswa. Guru harus mampu memberikan motivasi dan meningkatkan semangat belajar murid. Jika seorang guru kurang menarik di mata siswa maka akan berdampak pada tingkat kecerdasan dan minat belajar peserta didik. Jika kita menjabarkan peran guru dalam proses belajar mengajar maka dapat dirincikan sebagai berikut: peraga, pengelola kelas, mediator atau fasilitator dan evaluator.

Seorang guru yang profesional dapat dilihat dari kewenangan guru dalam melaksanakan peran keguruannya. Profesional berarti memiliki keahlian dan kemampuan khusus dalam menjalankan pekerjaannya. Sehingga guru yang profesional adalah orang yang betul-betul terlatih dan terdidik dan kaya akan pengalaman dan ilmu pengetahuan di bidangnya. Memiliki pendidikan formal bukan jaminan seseorang bisa dikatakan profesional tetapi mereka yang menguasai teknik dan strategi kegiatan belajar mengajar. Kompetensi itulah yang harus dimiliki oleh seorang guru profesional.

Berdasarkan fakta dan data dilapangan pada saat melakukan penelitian dan dari beberapa hasil wawancara dengan informan guru kelas di SD Negeri 4 Batukara bahwa guru kelas yang ada di SD Negeri 4 Batukara sudah menjalankan tugas dan fungsinya sebagaimana perannya yaitu fasilitator yang baik. Namun mereka mengakui belum pernah mengikuti pelatihan fasilitator hanya belajar melalui media sosial atau referensi-referensi lain yang berkaitan dengan teknikteknik menjadi fasilitator yang baik. Kedepannya mereka akan berusaha mengikuti pelatihan fasilitator jika ada lembaga yang menyelenggarakan fasiltator untuk meningkatkan keterampilan mereka dimasa yang akan datang.

Guru Kelas Tidak Bertindak Sewenang Wenang

Berdasarkan hasil penelitian dan data yang ditemukan penulis dilokasi penelitian pada saat melakukan penelitian bahwa peran guru kelas sebagai fasilitator di SD Negeri 4 Batukara yaitu guru kelas tidak bertindak sewenang wenang. Guru merupakan pemimpin, ibarat seorang pemimpin, sifat utama yang harus dimiliki adalah bersikap adil dan tidak sewenang-wenang. Maka tantangan terbesar seorang guru di era modern saat ini adalah bagaimana untuk bersikap konsisten dalam menegakkan keadilan atau bisa disebut dengan tidak sewenangwenang. Adil disini berarti memberikan hak kepada yang hak dan tidak memihak. Namun, perkara adil ini bukanlah hal yang mudah. Karena setiap anak didik menuntut keinginan dibimbing dan diperhatikan oleh seorang guru. Sehingga kemampuan guru dalam memahami siswa harus kuat. Guru harus memperlakukan siswa dengan sikap setara dan tidak membeda-bedakan antara murid yang cerdas dan cepat belajar dengan murid yang agak lambat dalam memahami pelajaran. Tanpa sikap adil yang dimiliki seorang guru, maka ia akan cenderung menyukai murid-murid yang pintar saja. Hal ini juga tentunnya harus ditunjukan oleh semua guru kelas di SD Negeri 4 Batukara.

Sifat untuk tidak memihak, guru dibutuhkan dalam penyelesaian konflik yang seringkali terjadi di kelas. Guru harus mampu memberikan keputusan terbaik bagi semua anak didik. Pemberian teguran dan pujian juga harus diperhatikan oleh seorang guru. Memberi pujian dan teguran sesuai dengan batas wajar. Memuji berlebihan dapat menyebabkan anak menjadi tinggi hati. Begitu pun sebaliknya, teguran yang berlebihan memicu anak menjadi stress dan dapat melakukan hal-hal tercela. Namun, dalam memberikan teguran juga harus didasari dengan rasa kasih 
sayang dan bukan didorong oleh rasa amarah dan hawa nafsu yang tak terkendali. Memberikan teguran juga berdampak pada perubahan sikap dan mental anak. Semakin ia ditegur maka semakin ia berani menentang. Maka dari itu, hendaknya seorang guru atau pendidik untuk selalu menjaga lisannya dan menjaga wibawanya. Seorang guru harus mampu memperlakukan semua anak didiknya seperti anaknya sendiri. Jika salah satu dari murid merupakan anaknya ia pun harus berani menghukum ketika berbuat keliru.

Berdasarkan fakta dan data dilapangan pada saat melakukan penelitian dan dari beberapa hasil wawancara dengan informan, guru kelas di SD Negeri 4 Batukara bahwa guru kelas terkhus kelas V dan Kelas VI tidak bertindak sewenangwenang terhadap siswa-siswinnya. Hal ini mereka sadari bahwa tindakan sewenang-wenang dapat memberikan dapak yang tidak baik bagi siswa-siswi terkhus yang ada di SD Negeri 4 batukara. Tindakan sewenag-wenang juga sangat bertentangan dengan etika peofesi sebagai guru atau tugas dan fungsi seorang guru. Mereka berusaha selalau adil dalam bertindak agar siswa-siswi tidak dirugikan dengan tindakan kami. Olehnya itu mereka menganggap guru kelas yang baik adalah guru yang selalu memberikan rasa adil bagi siswa-siswinya dan tidak bertindak sewenang-wenang.

\section{PEMBAHASAN}

Peran guru kelas sebagai fasilitator di Sekalah dasar Negeri 4 Batukara Kecamatan Batukara Kabupaten Muna yaitu:

\section{Guru Kelas Menyediakan Seluruh Perangkat Pembelajaran}

Berdasarkan hasil penelitian di SD Negeri 4 Batuka ditemukan peran guru kelas sebagai sebagai fasilitator yaitu menyiapkan perangkat pembelajaran. Perangkat pembelajaran yang dimaksud adalah silabus pembelajaran, lembar penialaian, absen kelas maupun instrumen praktikum-pratikum dasar, dan bukubuku belajar siswa. sebagai seorang fasilitator ini merupakan tanggung jawab seorang guru kelas dalam menyiapkan perangkat pembelajaran. Hal ini sesuai dengan pendapat yang dikemukakan oleh wahana (2001: 49) mengatakan bahwa perangkat diartikan sebagai perlengkapan, sedangkan pembelajaran adalah usahausaha yang terencana dalam memanipulasi sumber-sumber belajar agar terjadi proses belajar dalam diri siswa. Jadi perangkat pembelajaran dapat diartikan alat kelengkapan yang digunakan untuk pembelajaran. Dengan demikian, peran guru kelas sebagai fasilitator di SD Negeri 4 Batukara sudah menyediakan seluruh perangkat pembelajaran. Kelengkapan perangkat pembelajaran yang dimiliki guru kelas SD Negeri 4 Batukara terkhusus untuk kelas V Dan kelas VI seperti silabus pembelajran, lembar penilaian, absen kelas, instrumen praktikum-pratikum dasar, dan buku-buku belajar siswa.

\section{Guru Kelas Menyediakan Fasilitas Pembelajaran}

Berdasarkan hasil penelitian di SD Negeri 4 Batukara ditemukan peran guru kelas sebagai fasilitator yaitu guru kelas menyediakan fasilitas pembelajaran. Fasilitas pembelajaran yang disipkan oleh guru kelas di SD Negeri 4 Batukara berupa fasilitas sarana dan prasarana yang digunakan untuk proses pembelajaran. Sarana dan prasarana yang ada di SD Negeri 4 Batukara yaitu 6 ruangan untuk proses belajar siswa-siswi, ada 1 rungan kantor, 1 ruangan perpustakaan, 1 ruang UKS, ada lapangan sebagai sarana bermain dan olahraga siswa-siswi dan buku bacaan siswa. Hal ini sesuai dengan pendapat yang dikemukakan oleh The Liang Gie (2002 : 33) dalam bukunya yang berjudul cara belajar yang efisien, mengatakan bahwa untuk belajar yang baik hendaknya tersedia fasilitas pembelajaran yang memadai antara lain tempat atau ruang belajar, penerangan yang cukup, buku-buku 
pegangan dan perlengkapan praktek. Hal lain dikemukakan Tu'u (2004: 84) faktor sarana yang dapat mempengaruhi hasil belajar siswa seperti gedung, ruangan, penerangan, buku-buku, meja, kursi, dan alat praktek. Sarana sekolah yang baik akan membantu pencapaian hasil belajar yang baik. Dengan demikian peran guru kelas sebagai fasilitator di SD Negeri 4 Batukara sudah menyediakan fasilitas pembelajajan, fasilitas pembelajaran yang tersedia di SD Negeri 4 Batukara yaitu berupa sarana dan prasana, seperti gedung sekolah, ruang belajar, ruang UKS, lapangan olahraga, buku-buku dan instrument-instrumen praktek pembelajaran.

\section{Guru Kelas Sebagai Mitra.}

Berdasarkan hasil penelitian di SD Negeri 4 Batukara ditemukan peran guru kelas sebagai fasilitator yaitu guru kelas sebagai mitra. Guru kelas di SD Negeri 4 Batukara sudah bertindak sebagai mitra misalnya guru kelas selalu memberikan andil bagi siswa-siswi SD Negeri 4 Batukara, terlibat dalam proses belajar, tidak bertindak sebagai eksekutor dalam proses belajar di Sekolah. Disisi lain guru kelas bertindak sebagai mitra, maka guru kelas dapat mengetahui karakter-karakter siswa-siswi. Hal ini sesuai dengan pendapat yang dikemukakan Prastowo (2014 : 102) mengemukakan peran guru sebagai fasilitator yaitu memfasilitasi kegiatan belajar pada siswa, memberikan kesempatan pada siswa untuk bertanya dan melayani pertanyan mereka, memberikan ruang sepenuhnya agar mereka bisa berekspresi sesuai tema pelajaran, memberikan kesempatan kepada siswa untuk menjelaskan atau mengungkapkan pemahaman mereka dan memberi kemudahan kepada para siswa untuk melakukan aktivitas belajar. Sedangkan Djamarah Syaiful (2005: 37) mengatakan tanggung jawab seorang guru kelas bukan saja dalam sekolah, tetapi tanggung jawab guru diluar sekolah. Hal ini mau tidak mau harus menuntut guru kelas agar selalu memperhatikan sikap, tingkah laku dan perbuatan anak didiknya tidak hanya dilingkungan sekolah, tetapi diluar sekolah pun. Olehnya seorang guru kelas selalu bekerjasama dengan siswanya. Dengan demikian peran guru kelas sebagai fasilitator di SD Negeri 4 Batukara sudah bertindak sebagai mitra. Guru bertindak sebagai mitra dimana guru kelas di SD Negeri 4 Batukara senantiasa bekerja sama dalam siswanya baik dilingkungan sekolah atau diluar lingkungan sekolah, dan selalu tidak menempatkan diri sebagai eksekutor dalam kelas, melainkan siswa-siswi diberikan andil misalnya memberikan kesempatan bertanya pada saat belajar, serta menciptakan ha“rmonisasi dalam proses belajar dalam ruang kelas.

\section{Guru Kelas Melaksanakan Tugas Dan Fungsinya}

Berdasarkan hasil penelitian di SD Negeri 4 Batukara ditemukan peran guru kelas sebagai fasilitator yaitu guru kelas melaksanakan tugas dan fungsinya. Guru kelas di SD Negeri 4 Batukara mempunyai tugas dan fungsi yang sangat beragam. Tugas tersebut meliputi bidang profesi seperti guru kelas harus mendidik, mengajar dan melatih. Hal ini sesuai dengan pendapat yang dikemukakan oleh Daud (2008: 32) ada enam tugas dan fungsi guru dalam mengenbangakan profesinya yaitu guru sebagai pengajar, guru sebagai pembimbing, guru sebagai administrator, guru sebagai pengembang kurikulum, guru bertugas untuk mengembangkan profesi dan guru bertugas membina hubungan dengan masyrakat. Sedangkan dalam undangundang No 14 tahun 2005 pasal 1 ayat 1 guru adalah pendidik yang profesional yang 
tugas utama mendidik, melatih, menilai dan mengevaluasi peserta didik pada pendidikan usia dini jalur pendidikan formal, pendidikan dasar dan pendidikan menengah.

Berdasarkan pendapat diatas dapat disimpulkan bahwa peran guru kelas sebagai fasilitator di SD Negeri 4 Batukara sudah melaksanakan tugas dan fungsinya. Guru kelas SD Negeri Batukara menjalankan tugas dan fungsinya seperti mendidik, mengajar dan melatih. Selain itu tugas dan fungsinya adalah memotivasi, mendorong dan memberikan stimulus pada siswa-siswi dalam proses belajar di kelas. Disisi lain guru kelas SD Negeri 4 Batukara menjalankan tugas dan fungsi sebagaimana admintrator bagi siswa-siswi mereka, melakukan pembimbingan dan membina hubungan kerjasama dengan masyarakat serta orang tua siswa-siswi.

\section{Guru Kelas Tidak Bertindak Sewenang Wenang}

Berdasarkan hasil penelitian di SD Negeri 4 Batukara ditemukan peran guru kelas sebagai fasilitator yaitu guru kelas tidak bertindak sewenang wenang. Tindakan sewenang-wenang dapat memberikan dampak yang tidak baik bagi siswasiswi terkhus yang ada di SD Negeri 4 Batukara. Tindakan sewenang-wenang juga sangat bertentangan dengan etika peofesi sebagai guru atau tugas dan fungsi seorang guru. Guru kelas SD Negeri 4 Batukara selalau adil dalam bertindak agar siswa-siswi tidak dirugikan dengan tindakan yang sewenang-wenang. Hai ini sesuai dengan pendapat yang dikemukakan oleh Wina Sanjaya (2006: 257) peran guru sebagai fasilitator dapat diukur dengan indikator salah satunya adalah guru kelas tidak bertindak sewenang-wenang. Sedangkan menurut E. Mulyasa (2011: 53) mengatakan seorang guru sebagai motivator harus memperhatikan prinsip-prinsip memberikan tugas yang jelas dan dapat dimengerti. Memberikan penghargaan terhadap hasil kerja dan prestasi anak didik. Memberikan penilaian dengan adil dan transparan. Berdasarkan pendapat diatas dapat disimpulkan bahwa peran guru kelas sebagai fasilitator di SD Negeri 4 Batukara, guru kelas tidak bertindak sewenang-wenang terhadap siswa-siswi yang ada di SD Negeri 4 Batukara. Terkhusus kelas V dan kelas VI mereka merasa senang terhadap guru kelas mereka. Selama dalam proses belajar dalam kelas guru kelas mereka selalu ramah dan selalu berlaku adil terhadap siswa-siswi.

\section{SIMPULAN}

Berdasarkan hasil penelitian dan pembahasan dapat ditarik kesimpulan bahwa peran guru kelas sebagai fasilitator di Sekalah Dasar Negeri 4 Batukara Kecamatan Batukara Kabupaten Muna, dilihat dari beberapa indikator yaitu (1) guru kelas harus menjadi inisiator agar proses belajar dapat berjalan maksimal dan tidak membebankan perangkat pembelajaran kepada siswa untuk memperadakannya. (2) guru kelas sudah bertindak sebagai mitra dalam proses belajar, maka guru kelas dapat mengetahui karakter-karakter siswa-siswi, (3) guru kelas menjalankan tugas dan fungsinya sebagaimana tugas utama sebagai guru dalam hal ini menjadi fasilitator dengan baik. (4) tidak bertindak sewenang-wenang terhadap siswa-siswinnya. 


\section{UCAPAN TERIMA KASIH}

Penulis menyampaikan ucapan terima kasih dan penghargaan kepada Ibu Kabiba, S.Pd., M.Pd. selaku pembimbing I dan Ibu Nurzaima, S.Pd., M.Pd selaku pembimbing II yang telah sabar, tekun, tulus dan ikhlas meluangkan waktu, tenaga dan pikiran memberikan bimbingan, motivasi, arahan, dan saran-saran yang sangat berharga kepada penulis selama menyusun hasil ini, dan seluruh civitas akademika Program Studi Administrasi Pendidikan, Fakultas Keguruan dan Ilmu Pendidikan, Universitas Muhammadiyah Kendari.

\section{DAFTAR PUSTAKA}

Djamarah Syaiful, Bahri. 2005. Guru Dan Anak Didik Dalam Interaktif Edukati, Cet.3. Jakarta: PT Rineka Cipta

Daud, udin syefudin. (2008). Pengembangan Profesi Guru. Bandung : Alfabeta

Esi Dkk. 2016. Peranan Guru Sebagai Fasilitator Danmotivator Dalam Meningkatkan Hasil Belajar Di Kelas XI SMK. Jurnal Pendidikan dan Pembelajaran khatulistiwa Vol.No.10.

Denny Boy Mochran, dkk. 2014. Coral Triangle center: Buku Saku Fasilitator. Danau Tamblingan 78 Sanur: Bali

Mulyasa, E. 2011. Sertifikasi Kompentensi Dan Sertifikasi Guru. Bandung: Remaja Rosdakarya

Parker, W. H. 2007. Etiology, Symptomatology, and Diagnosis of Uterine Myomas Volume 87. Departement of Obstetrics and Gynecology UCLA School Medicine: California: American Society for Reproductive Medicine.

Prastowo, Andi. (2014). Panduan Kreatif Membuat bahan Ajar Inovatif. Yogyakarta: Diva Press

Sugiyono. 2007. Metodologi Penelitian Bisnis. Jakarta: PT. Gramedia.

The Liang Gie. 2002. Cara Belajar Yang Efisien. Yogyakarta: Liberty

Tu'U, Tulus. 2004. Peran Disiplin Pada Perilaku dan Prestasi Siswa. Jakarta: Grasindo

Undang-Undang No 14 Tahun 2005 Tentang Guru Dan Dosen. Bandung: Citra Umbara.

Usman, Moh. Uzer. 2007. Menjadi Guru Profesional. Bandung: Rosdakarya.

Wahana. 2001. Perencanaan Dan Pengelolaan Pembelajaran IPA. Jakarta: Pusat Penerbitan Universitas Terbuka.

Wina Sanjaya. 2006. Strategi Pembelajaran. Jakarta: Kencana Prenada Media Group. 